\title{
THE INSTITUTIONAL BASED FISHERIES' RESOURCES MANAGEMENT OF AMBON ISLAND, INDONESIA
}

\author{
Sapulette Alce Albartin \\ State Christian Institute of Ambon, Indonesia \\ E-mail: sapulettealce@gmail.com
}

\begin{abstract}
The purpose of this study was to analyze a Sasi institutional element in the management of fisheries resources in the island of Ambon. To get the data needed, a serial of in-depth interview and library research was conducted to the participants of several customary leaders. After data collected then analyzed using a qualitative method based on the phenomenological approach. The results showed that Sesi was found that the institutional function in the management of fisheries resources has been effective functioned as follows: First, regional boundaries. institutional Sasi has clear regional boundaries. Determination of boundaries conducted through deliberations led and initiated by customary leaders. Second, the rule system of Sasi has an institutional rule and restrictions on resource management. Third, the punishment is given in the form of customs penalties, monetary fines, and confiscation of fishing gear. Fourth, institutional Sasi entitled to regulate the activities allowed and prohibited. Fifth, Sasi has authority to use of natural resources in coastal areas. Sixth, institutional Sasi has a resource monitoring mechanism that works with other parties.
\end{abstract}

\section{KEY WORDS}

Fisheries, resources, management, coastal area.

Indonesia is the largest archipelago country in the world with a coastline length of around $95000 \mathrm{~km}$, the area of seawater reaches 5.8 million km2 and about 13492 islands. Overall the potential of coastal and marine resources is the main source of growth and support to support sustainable development (Alikodra 2012). An important aspect of fisheries management is the actors involved in the management process. These actors can be classified into 3 groups, namely government (government-based management), community (community-based management), and their cooperation (co-management). According to Satria (2015), community-based fisheries management systems recognize and consider the role of the community traditional fishermen and has long been applied in Indonesia (Satria \& Matsuda 2004). Local community-based management is clearly considered capable of maintaining ecosystems and the sustainability of fishery resources (Cinner \& Aswani 2007). Through local wisdom, the community sees that there are responsibilities in utilization activities, and responsible for protecting natural resources (Berkes, 2008).

One form of local wisdom in fisheries management is the institutional Sasi found in Ambon, Maluku. The Sasi is generally known as a traditional natural resource management system carried out by people in eastern Indonesia, including Maluku and Papua. The Sasi is a system of beliefs, rules, and rituals that involve temporary prohibitions on the use of resources or certain regions (Adhuri, 2013). Various studies show the degradation of Sasi institutions due to the decline of the legitimacy of local authorities and the competent leaders of Sasi institutions, as it happened in Central Maluku (Harkes and Novaczek, 2002) and Raja Ampat (McLeod, et al., 2009). Sasi has also been largely abandoned in most areas in the Kei archipelago, Maluku, except in some areas on the east coast of Kei Besar (Adhuri, 2013). Based on the description above, it is important to analyze institutional element sasi in managing resources. Based on the description of the background above, the purpose of this study is to analyze the institutional elements of sasi in managing coastal resources. 


\section{METHODS OF RESEARCH}

This study used descriptive qualitative methods. This research was conducted on the island of Ambon, Maluku. The choice of location is done intentionally (purposive). Data collected includes primary data and secondary data. Primary data is obtained from observation, in-depth interviews, and focus group discussions or focused group discussions (FGD). Secondary data was obtained from the village office, the Statistic Central Agency, Ambon Fisheries, and Marine Service and previous research reports. Data analysis techniques were data collection, data analysis, data reduction, data presentation, and conclusion.

\section{RESULTS AND DISCUSSION}

Sasi is a form of traditional knowledge management based on local knowledge and wisdom. Its existence has existed from the past in the ancestral community of the island of Ambon. Historically this local wisdom system was widespread in several coastal areas of Indonesia, such as in Aceh with Panglima Laot (Mustaqim 2018), Lombok with institutional Awig-awig, and in Maluku with sasi institutions. Traditional natural resource management practices have been carried out for centuries in various communities in the world. Before the colonial government entered Indonesia, the orientation of the implementation of Sasi was aimed at protecting the community from over-exploitation activities. Post-reform of resource management is carried out through decentralization. Recognition of Sasi institutions as a mechanism for sustainable natural resource management is also driven by the surge in environmentalism that has occurred in the world and has been started since the 1980s (Zerner, 1994). The challenges of change that threaten the course of Sasi in many villages in Maluku and parts of West Papua, which are related to the commercialization, modernization, and fading of traditional values (Harkes \& Novaczek, 2002). The occurrence of Sasi commercialization is also indicated by the implementation of the Sasi auction system as mentioned in (Harkes \& Novaczek, 2002).

Sasi is an institution built by the community to manage fisheries resources. There are eight institutional performance indicators in resource management (Ontrom, 1990). Institutional performance indicators are regional boundaries, rules, sanctions, rights systems, authority, and supervision

The boundary of the territory is the clarity of the regional boundaries whose criteria are containing valuable resources for the community (Satria, 2015). Regional boundaries are generally carried out by means of a straight line drawn towards the sea from the outermost land to the edge of the coral reef (Solihin 2010). Sasi has clear territory and boundaries. Determination of boundaries conducted through deliberations led and initiated by customary leaders. According to the head of the custom, the determination of management area boundaries is based on the location of the resource. Determination of regional boundaries is adjusted to the distance of the community in fishing activities. The boundary of the coastal area which is 500 meters away is measured from the coast to the sea with a length of 800 meters measured from the outermost distance towards the side. The purpose of determining boundaries is to facilitate supervision of coastal resources.

The Rules system is a shared understanding between several parties which shows strong clues about the actions that are required, prohibited or allowed (Ostrom 2011). Rules contained in the sasi are based on traditional provisions which tend to be unwritten. This rule is passed down verbally to the community. At the research location, there are rules for opening and closing Sasi. Open sasi is an activity for taking fisheries resources by the community. Sasi opening system began with a traditional ceremony. Whereas closing Sasi is an activity that signifies the end of resource extraction. The activity is carried out by the installation of the end of the opening session. When the sasi is closed, the community may only cross the designated area, it is not permissible to take the results from the area being monitored (Lestari and Satria, 2015). At present, the rules are clearer and understandable because they are made more formally in the form of village regulations. 
The sanction system is a provision imposed on every society that violates the rules in utilizing resource use. In the management of fisheries resources, the application of sanctions becomes an important instrument. The most influential tool in determining the sustainability index value is sanctioned for fishermen who break the law (Chaliluddin et al., 2014). There are several types of sanctions for social sanctions (such as being humiliated or ostracized by the community), economic sanctions (fines, confiscation of goods), moral sanctions (through formal court mechanisms) and physical sanctions (Satria, 2015). These sanctions have been made in a more assertive and more repressive form than customary law in general (Witanto 2007). Giving sanctions to the community based on the level of violations committed. The form of sanction given to people who break regulations Sasi institutions can be seen in the following table 1:

Table 1 - Sanction System

\begin{tabular}{|c|c|c|}
\hline No. & Form of violation & Sanctions \\
\hline 1 & $\begin{array}{l}\text { Using explosives } \\
\text { and potassium in the sasi area; }\end{array}$ & Pay a fine of IDR. 500,000 and be ostracized by the community; \\
\hline 2 & $\begin{array}{l}\text { Collecting sea products in the sasi area } \\
\text { before opening time; }\end{array}$ & Pay a fine of IDR. 300,000 , and the fishing gear is confiscated; \\
\hline 3 & $\begin{array}{l}\text { Dispose of dirt or garbage in the sasi } \\
\text { area; }\end{array}$ & $\begin{array}{l}\text { Pay a fine of IDR } 50,000 \text { and clean the place of worship (Mosque } \\
\text { for } 3 \text { days); }\end{array}$ \\
\hline 4 & Eliminate sanction marks intentionally; & $\begin{array}{l}\text { Sanctions from nature (belief system) are in the form of } \\
\text { possession and paralysis. in addition, sanctions from the public } \\
\text { are public humiliation; }\end{array}$ \\
\hline 5 & $\begin{array}{l}\text { Using marine vehicles that cause noise } \\
\text { in the area; }\end{array}$ & $\begin{array}{l}\text { Pay a fine of IDR. } 15,000 \text { and clean the place of worship for } 2 \\
\text { days; }\end{array}$ \\
\hline 6 & $\begin{array}{l}\text { Carry out fishing activities around the } \\
\text { Sasi area. }\end{array}$ & A fine of IDR. 30,000 clears the place of worship for 3 days. \\
\hline
\end{tabular}

Sanctions are given with the aim of not only providing trauma or feeling of the deterrent to the offender, but to educate the offender not to do the same. According to Kuwati et al., (2014), the mechanism for giving sanctions to offenders depends on the customer leader, the punishment can be in the form of physical activities, fines, and taking fishing gear.

The rights system in this study refers to a set of ownership rights (Satria, 2009). It must support spatial certainty and incentives for management. This rights system must be able to exclude and refuse claims of benefits to unauthorized parties (Hall et al. 2011; Scott 2008). The rights system must be legitimate and effectively recognized so that it does not require additional costs to implement it. Sasi institutions have the right to regulate any activities that are permitted and prohibited in taking advantage of fisheries resources in Ambon Island. Whereas customary rights in the research location there are several rights attached to the sasi institution: 1). the right to determine the time and opening ceremony; 2). the right to determine the type of fishing gear; 3). the right to enforce sasi legal rules; (4). Auction rights; 5). the right to determine the boundaries of the sea sasi area; (6). the right to grant a business license, and (7). the right to resolve fisherman conflicts.

Authority is the legitimate power possessed by an institution to carry out its duties and functions. The authority holder is an institution formed by the community, both formal and informal, to regulate the management mechanism, creating rules, revise rules, and make decision-making mechanisms. The authority to implement the rules and customary law of the sea in Ambon was represented through the sasi institution. In running its function, sasi has an authority structure in decision making, namely the existence of a customary leader who has a role in management. The role of the head of Kewang includes decision making, as well as internal and external affairs related to sasi responsibilities. Decision making both related to internal and external affairs by kewang is carried out through the deliberation of the Deliberation led and initiated by the customary head. Decision making related to violations committed by the community is adjusted to the applicable norms and rules.

Community-based fisheries management is a process of giving authority, responsibility, and supervision to the community to manage resources by paying attention to their needs, desires, goals, and aspirations (Nikijuluw 2000). Supervision of fisheries resources is carried 
out by the fishing community through the rules of the sasi institution and assisted by community social institutions. Supervision with sasi aims to see the level of public compliance with the rules and impose sanctions on violators. The oversight mechanism is carried out by reporting to customary leaders such as village heads, customary leaders and religious leaders or can immediately expel perpetrators who commit violations. Techniques in supervision carried out in the form of patrols were also carried out by the government.

\section{CONCLUSION}

Sasi is a form of common (pool) resource management practice which has been implemented for generations in Ambon island, Maluku. One of local wisdom of Maluku is known as sasi.

Sasi was a form of resources management based on local society. It has long been trusted as one of the most efficient traditional practices in maintaining the sustainability of resources in coastal areas. The results showed that Sesi was found that the institutional function in the management of fisheries resources has been effective functioned as follows: First, regional boundaries. institutional Sasi has clear regional boundaries. Determination of boundaries conducted through deliberations led and initiated by customary leaders. Second, the rule system of Sasi has an institutional rule and restrictions on resource management. Third, the punishment is given in the form of customs penalties, monetary fines, and confiscation of fishing gear. Fourth, institutional Sasi entitled to regulate the activities allowed and prohibited. Fifth, Sasi has authority to use of natural resources in coastal areas. Sixth, institutional Sasi has a resource monitoring mechanism that works with other parti

\section{REFERENCES}

1. Adhuri, Dedi Supriadi. 2013. Selling the Sea, Fishing for Power: A Study of Conflict over Marine Tenure in Kei Islands, Eastern Indonesia. ANU E.Press.

2. Alikodra, Hadi S. 2012, Konservasi Sumber Daya Alam and Lingkungan Pendekatan Ecosophy bagi Penyelamatan Bumi, cetakan ke-1, Gadjah Mada Universityy Press:Yogyakarta.

3. Berkes, Fikret. 2008. Community conserved areas: policy issues in historic and contemporary context. Conservation Letters 2(1), pp.19-24.

4. Chaliluddin, Purbayanto A, Monintja DR, Imron M, Santoso J. 2014. Institution of panglima laot in supporting sustainable capture fisheries based on local wisdom in aceh jaya district. IJSBAR. 16(2):147-163.

5. Cinner J. E., Aswani S., 2007 Integrating customary management into marine conservation. Marine Policy 40 (2007):201-216.

6. Cinner J. E., Basurto X., Fidelman P., Kuange J., Lahari R., Mukminin A., 2012 Institutional design of customary fisheries management arrangements in Indonesia, Papua New Guinea, and Mexico. Marine Policy 36:278-285.

7. Kuwati M M 2014 Konservasi Berbasis Kearifan Lokal (Studi Kasus: Sasi Di Kabupaten Raja Ampat) Prosiding Seminar Nasional Raja Ampat "Raja Ampat And Future Of Humanity (As A World Heritage)" (Wasai: Universitas Satya Wacana Salatiga) pp. 8-9.

8. Mustaqim, 2018 Analysis of fishery institutional sustainability factors in Sabang Island Aceh Province, Indonesia. AACL Bioflux 11(4):1222-1230.

9. Hall D, Hirsch P, Li TM. 2011. Powers of Exclusion: Land Dilemmas in Southeast Asia. Singapore: NUS Press.

10. Harkes, Ingvild, and Irene Novaczek. 2002. Presence, performance, and institutional resilience of sasi, a traditional management institution inCentral Maluku, Indonesia. Ocean \& coastal management 45(4), p.237-260.

11. McLeod, Elizabeth, Brian Szuster, Rodney Salm. 2009. Sasi and Marine Conservation in Raja Ampat,Indonesia. Coastal Management 37(6), pp.656-676.

12. Nikijuluw, V.P.H, 2002. Rezim Pengelolaan Sumber Daya Perikanan, Pustaka Cidesindo. Jakarta. 
13. Ostrom, Elinor. 1994. Institutional Analysis, Design Principles and Threats to Sustainable Community Governance and Management of Commons. In Pomeroy (ed.) Community management and common property of coastal fisheries in Asia and the Pacific: concepts, methods and experiences. ICLARM Conference Prosiding, p. 34-50

14. Ostrom, E. 2011. Background on the Institutional Analysis and Development Framework. The Policy Studies Journal, Vol.39, No.1,

15. Satria A., Matsuda Y., 2004 Decentralization of fisheries management in Indonesia. Marine Policy 28(5):437-450.

16. Satria A., 2015 Pengantar Sosiologi Masyarakat Pesisir. Jakarta (ID): Yayasan Pustaka Obor Indonesia.

17. Scott, W Richard. 2008. Institutions and Organizations: Ideas and Interests 3rd edition. Los Angeles: Sage Publications.

18. Solihin A., 2010 Politik Hukum Kelautan \& Perikanan: Isu, Permasalahan, and Telaah Kritis Kebijakan. Bandung (ID): Nuansa Aulia.

19. Witanto DY. 2007. Hukum adat laut sabang: kearifan-kearifan yang terlupakan. Banda Aceh (ID): Yayasan Pemberdayaan Masyarakat Daerah Aceh (PEMADA). 